\title{
Tannery effluent effect on the haematological parameters of freshwater fish, Channa punctatus
}

\author{
S. Parveen ${ }^{1}$, D. Singh ${ }^{2}$, Ram Bharose ${ }^{1}$, S. Rout ${ }^{1 *}$, M. A. Khan ${ }^{3}$ and E. F. Ansari ${ }^{2}$ \\ ${ }^{1}$ School of Forestry and Environment, Sam Higginbottom Institute of Agriculture Technology and Sciences, \\ Allahabad-211007 (Uttar Pradesh), INDIA \\ ${ }^{2}$ Department of Environmental Science, Chhatrapati Shahu ji Maharaj University, Kanpur- 208024 (Uttar Pradesh), \\ INDIA \\ ${ }^{3}$ Department of Crop Physiology, Chandra Shekhar Azad University of Agriculture and Technology, Kanpur- \\ 208002 (Uttar Pradesh), INDIA \\ *Corresponding author. E-mail: srout.forestry@gmail.com
}

Received: May 2, 2016; Revised received: November 4, 2016; Accepted: January 20, 2017

\begin{abstract}
The present investigation was undertaken to evaluate the tannery effluent toxicity stress symptoms in fish blood during a long term of exposure period. The effect of tannery effluent on various haematological parameters were evaluated exposing fresh water fish, C. punctatus to different concentration i.e., [Control, $5 \%$ Tannery effluent (TE), $10 \%$ TE and $20 \%$ TE] of tannery effluent. Exposed of fish to tannery effluent showed a significant decrease in the haemoglobin $(\mathrm{Hb})$ content $(9.16 \pm 0.08)$, red blood cells $(3.32 \pm 0.12)$, packed cell volume $(34.66 \pm 0.33)$ and mean corpuscular haemoglobin $(\mathrm{MCH})$ values, whereas significant increase in the white blood cells (WBC), erythrocyte sedimentation rate (ESR) and clotting time was recorded with increase in exposure periods as compared to control respectively. $\mathrm{Hb}, \mathrm{RBC}$ and $\mathrm{MCHC}$ values showed fluctuating results. The haematological parameters were decreases from $15^{\text {th }}$ days of exposure periods to $45^{\text {th }}$ days of exposure period. The decrease in haematological parameters clearly indicates that the exposed fishes have become anemic due to tannery effluent exposure.
\end{abstract}

Keywords: Blood, Channa punctatus, Haemoglobin, Tannery effluent, White blood cells

\section{INTRODUCTION}

Rivers are the natural source of freshwater. Water pollution has become a global problem; it carries a load of dissolved and particulate matters from both natural and anthropogenic sources along with other contents. These substances move downstream and may cause chemical and biological changes in the quality of water. Thus, the water chemistry of a river is affected by the lithology of the reservoir, atmospheric, and anthropogenic inputs. Industrialization has become an important factor to the development of a country's economy, through the establishment of plants and factories. However, the waste or by-products discharged from them are severely disastrous to the environment. These waste products are various kind of contaminant which contaminates surface water, ground water and soil. The discharges from these industries constitute biohazard to man and other living organisms in the environment because they contain toxic substances detrimental to health (Adebisi et al., 2007; Adriano, 2001; Bakare et al., 2003). Recently, there has been an alarming and worrisome increase in organic pollutants (Nadal et al., 2004). Since many effluents are not treated properly, these products are discharged on the ground or in the water bodies and most of these discharges to water bodies accumulate in the system through the food chain (Odiete, 1999). The waste water discharge form industries are the major source of pollution and affect the ecosystem (Morrison et al., 2001). The degradation of the environment was due to the adverse effect of industrial waste on living organism and agriculture (Anikwe and Nwobodo, 2006).

Kanpur is also known as Industrial city in the world which is mainly famous for tanneries, footwear and leather industries. In the global scenario, Kanpur is the top and famous for tannery industries. The main reason of the pollution in Kanpur is due to the tannery. Only about $20 \%$ of chemicals used in the tannery process are absorbed by leather, rest of these were released as waste which absorbed by bioaccumulation process by flora and fauna (Sahu et al., 2008). The tannery industry is one of the oldest industries, which is unevenly scattered in the country. There are more than 2,500 tanneries located in different urban centers of India processing about 500,000 tones of hides and $314 \mathrm{~kg}$ skins per annum which generates about $100,000 \mathrm{~m}^{3}$ of wastewater per day (Sugasisni and Rajgopala, 2015). The discharge of tannery waste water increases from January to May because of higher production rate in tanning industry diurnal this time water quality 
decreases. Aquatic system is an ultimate sink of heavy metal pollutants and since aquatic animals tend to accumulate heavy metals from various sources including sediments, soil erosion and runoff, air depositions of dust and aerosol, and discharges of waste water (Goodwin et al., 2003) they provide the insights of toxicity mechanisms induced by these heavy metals.

Fish is an important component of human nutrition and those from contaminated sited present potential risk to human health. Abnormal physico-chemical characteristics of industrial effluents are responsible for mortality of fishes (Mishra et al., 1988; Pawar, 1988). Metals can accumulate in the aquatic organism including fish. When fish are exposed to elevated levels of metals in a polluted aquatic ecosystem they tend to take these metals up from the environment (Adakole, 2012). Haematological tests in fish are important diagnostic tools and valuable indicator of diseases or stress due to environment pollution (Kori-Siakere and Ubogu, 2008). Hence keeping in view the importance the present investigation was carried out to determine the effect of tannery effluent on haematological parameters of fresh water fish Channa punctatus.

\section{MATERIALS AND METHODS}

The study on tannery effluent toxicity on freshwater fish's C. punctatus was conducted to explore the tolerance and toxic limits against different level of diluting tannery effluents. The experiment on aquatic fish C. punctatus was conducted at Laboratory in Department of Environmental Science, I.B.S.B.T., C.S.J.M. University, Kanpur.

Collection of effluent sample: Tannery effluent is collected from the tannery located at Jajmau, Kanpur in 100 Liter of plastic container and transported to the laboratory.

Collection and acclimatization of fish sample: The small size freshwater fish, C. punctatus, weighing $20 \pm 2 \mathrm{~g}$ and measuring $11 \pm 2 \mathrm{~cm}$, were collected with the help of local fisherman from water bodies located in the sub region of Kanpur. The fish was properly washed in tap water and treated with $0.02 \%$ KMNO4 and $0.004 \%$ formalin solution to remove the external infection of fungi, algae, etc. Prior to the experimentation the normal uninfected healthy fish were selected for the experiment. The fish were acclimatized to laboratory conditions for 15 days before taken for experimentation. The animals were fed TOKYO made in Japan on a day at 8 pm every day.

Experimental set up: The bioassay study was conducted using tap water (University water supply) as dilution medium was estimated by the method of APHA, (2005). The fish were divided into 4 equal groups consisting of 10 each and each group was transferred separately to glass aquaria of $100 \mathrm{~L}$ volume. While the group I fish were maintained as the control without any treatment, the group II, III and IV fish were exposed to different concentration (5\% TE, $10 \%$ TE and 20\%TE) of tannery effluent for 15 and 45 days. The waste products were removed from aquaria water by using good quality of aquaria water filter. The changes in the Temperature, TDS $\mathrm{mgL}^{-1}, \mathrm{pH}, \mathrm{EC}$ $\mathrm{dSm}^{-1}$, DO $\mathrm{mgL}^{-1}$, BOD $\mathrm{mgL}^{-1}$, COD $\mathrm{mgL}^{-1}$, TH $\mathrm{mgL}^{-1}$, $\mathrm{TA} \mathrm{mgL}^{-1}$, Chloride $\mathrm{mgL}^{-1}$ of the experimental water were recorded throughout the experimental period.

Haematological study: The blood from the caudal vein of control and treated fish was collected for haematological investigation. $\mathrm{Hb}, \mathrm{RBC}, \mathrm{WBC}, \mathrm{ESR}$ and PCV were examined following the procedures of Wintrobe, (1957) and Sood, (1996). The anticoagulant heparin liquid power (5,000 I.U) was used for estimation of ESR and PCV.

Statistical analysis: The data observed in the experiment were statistically analyzed for the calculation of standard error (S.E.) and students' ' $t$ ' test was administered for testing the hypothesis with the help of computer software SPSS program. The data shown are the averages of three replicates \pm S.E.

\section{RESULTS AND DISCUSSION}

In the present study, exposure to various concentrations i.e., $5 \%, 10 \%$ and $20 \%$ of tannery effluent to fish, C. punctatus for $15^{\text {th }}$ and $45^{\text {th }}$ days of exposure periods caused significant alterations in haematological parameters. The alteration observed in various physicochemical parameters of tannery effluent along with tap water, such as, Temperature, TDS $\mathrm{mgL}^{-1}, \mathrm{pH}$, EC $\mathrm{dSm}^{-1}$, DO $\mathrm{mgL}^{-1}$, BOD $\mathrm{mgL}^{-1}$, COD $\mathrm{mgL}^{-1}$, TH $\mathrm{mgL}^{-1}$, TA $\mathrm{mgL}^{-1}$, Chloride $\mathrm{mgL}^{-1}$ and control of experimental system were indicated in Table.1. The $\mathrm{Hb} \%(11.20 \pm 0.11), \mathrm{RBC}(5.55 \pm 0.13)$, ESR and PCV $(35.33 \pm 0.33)$ increased significantly $(\mathrm{p}<0.05)$ for $5 \% \mathrm{TE}$ at $15^{\text {th }}$ day exposure periods, but increase in $10 \%$ TE was found after at $15^{\text {th }}$ day, and decreases $\mathrm{Hb} \%, \mathrm{RBC}, \mathrm{ESR}$ and $\mathrm{PCV}$ was recorded after at $45^{\text {th }}$ day of exposure period. $\mathrm{Hb} \%$ decreased significantly in $20 \% \mathrm{TE}$ at all exposure period. The maximum decrease in $\mathrm{Hb} \%$ was observed after longest exposure of $45^{\text {th }}$ days. The total red blood cells (RBCs) count also registered an increasing 5\% of tannery effluent in comparison to controls for $15^{\text {th }}$ and $45^{\text {th }}$ day of exposure periods. Whereas the decrease in total RBC count was significant $(\mathrm{p}<0.05)$ for $10 \%$ and $20 \%$ TE in $45^{\text {th }}$ day of the exposure periods. A significant increase in total white blood cells (WBC) count over and above controls was observed for all $(5 \% \mathrm{TE}, 10 \% \mathrm{TE}$ and $20 \%$ TE) three sets of exposure periods. The erythrocyte sedimentary rate (ESR) decrease at $15^{\text {th }}$ day exposed fish for $5 \% \mathrm{TE}$, and also increased significantly under stress condition for $45^{\text {th }}$ days of exposure periods respectively in comparison with control. All the values of ESR are significant at $\mathrm{p}<0.05$. The pact cell volume 
S. Parveen et al. / J. Appl. \& Nat. Sci. 9 (1): 201 - 205 (2017)
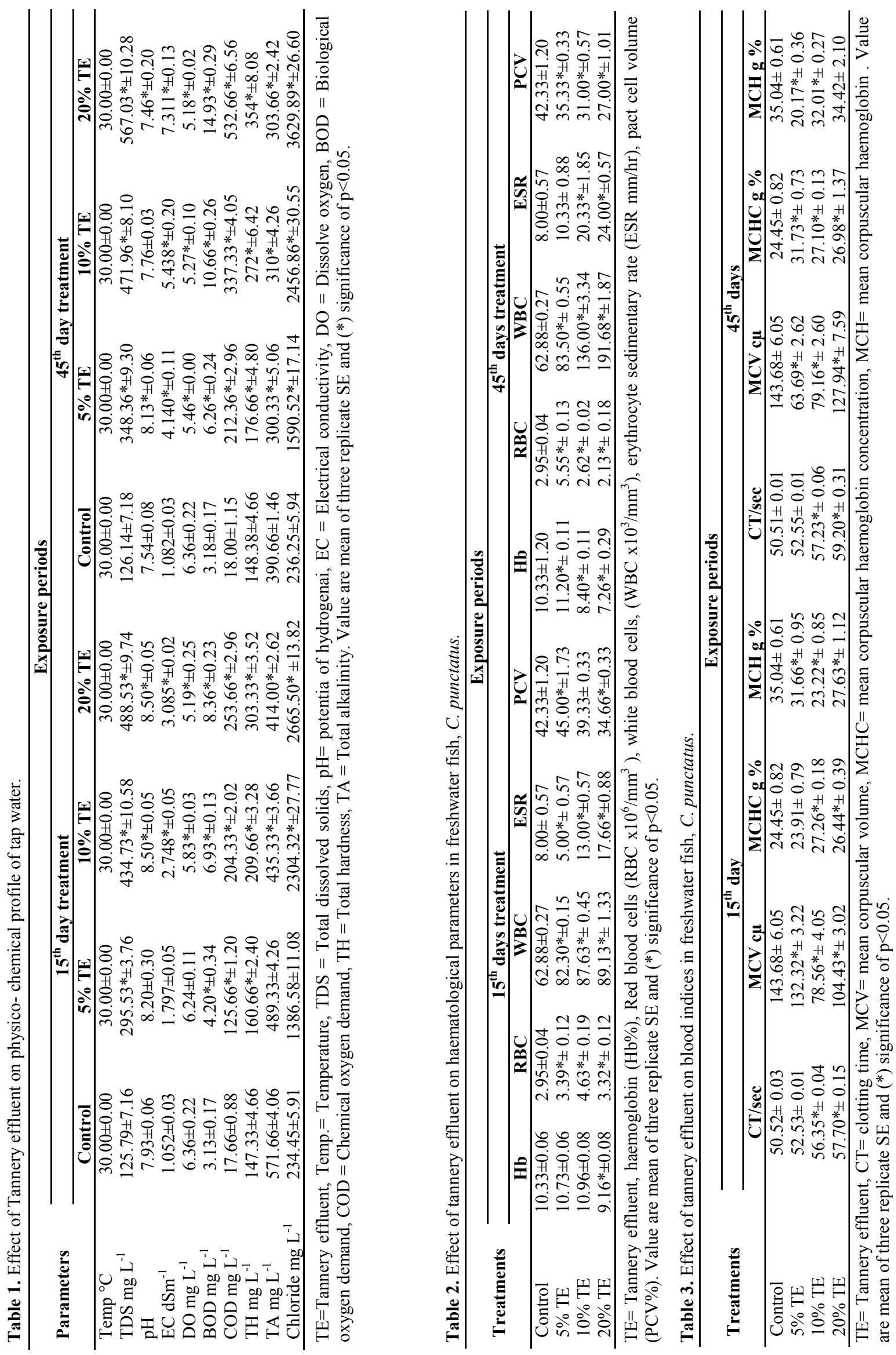
(PCV) was found increased in 5\% TE at $15^{\text {th }}$ day and also decreased significantly after $45^{\text {th }}$ day of exposure periods. The PCV was found decreased for $10 \% \mathrm{TE}$ and $20 \%$ TE significantly after $15^{\text {th }}$ and $45^{\text {th }}$ day of exposed fish (Table 2). The clotting time (CT) registered an increasing trend over and above controls for all exposure periods. The mean corpuscular volume (MCV) value, mean corpuscular haemoglobin $(\mathrm{MCH})$ and mean corpuscular haeamoglobin concentration (MCHC) values decreased after $15^{\text {th }}$ day $5 \%$ TE exposed fish, and MCHC values increased $45^{\text {th }}$ days of exposure to $5 \%, 10 \%$ and $20 \%$ TE exposed fish in comparison with control value (Table 3). Short term exposure to pollutants and low concentration of heavy metals mostly induce an increase in these haematological indices to tolerate the stress condition. Similar results were reported by Singh and Singh, (1982) in fish Mystus vittatus exposed to copper and Zinc Sulphate. Haniffa and Porchelvi (1985) and Bhatkar (2010) reported erythrocytosis and increase in haemoglobin after exposure to stress condition. This can be due to impairment of gas exchange. According to Shah (2006) it may be due to the consequent stimulation of erythropoesis or compensatory erythropoesis in fish Tinca tinca.

In the present study when the freshwater fish C. punctatus was exposed to various concentration of tannery effluent and evaluated haematological toxicity. The $\mathrm{Hb} \%$, RBC count and PCV\% was significantly increased after $15^{\text {th }}$ day of exposure period, but decreased $\mathrm{Hb} \%$, RBC count and $\mathrm{PCV} \%$ values after $45^{\text {th }}$ day of exposure period leading to anemia. The anemic condition of fish resulting from an unusually low numbers of red blood cells or too little haemoglobin content in the red blood cells Kori-Siakepere et al. (2006). Bhagwant and Bhikajee (2000) reported that the prolonged reduction in haemoglobin content is deleterious to oxygen transport and any blood dyscrasia and degeneration of the erythrocytes could be ascribed as pathological conditions in Oreochromis hybrid fish.

The fall in $\mathrm{RBC}$ count, $\mathrm{Hb} \%$ and $\mathrm{PCV} \%$, in the fish C. punctatus upon treatment with both copper and chromium, shows the occurrence of acute anemia in toxic condition Mallesh et al. (2015). Cirrhinus mrigala exposed to hexavalent chromium. A decrease in the concentration of haemoglobin in the blood, which is usually caused by the effect of toxic metals on gills, as well as a decrease in oxygen also indicates anemia or confirms negative changes occurring in fish. Singh et al. (2008) revealed in Cirrihna mrigala and Catla catla fishes that decreased haemoglobin percent, RBC count and PCV percent values leading to anemia. They also suggested that the anemia might have lead to fall in the red blood cell, haemoglobin concentration and hematocrit values and anemia under metal stress may be due to blood cell injury and disturbed haemo- globin synthesis. Hematocrit is also used to determine the ratio of plasma to corpuscles in the blood (Larsson et al., 1985) and hemopoietic functioning of tissues (Kori-Siakepere et al., 2006). Ates et al. (2008) also found the reduction in erythrocyte, haemoglobin and hematocrit values in fish Onchorynchus mykiss exposed to lead and copper which can be an indicator of anemia with the subsequent result of inhibition of erythropoietin in the hemopoietic organism.

The white blood corpuscles count was significantly increased in the experimental groups at the end of $15^{\text {th }}$ and $45^{\text {th }}$ day of exposure periods. Increased population of white blood corpuscles might indicates a stimulation of immune system to protect the fish against infections under hexavalent chromium toxicity. Singh, (1995) also found similar findings, increase in leucocytes count in C. punctatus exposed to chromium and copper, and in Cyprinus carpio exposed to hexavalent chromium (Shaheen, 2009). Leucocytes increased following copper exposure and were significantly higher in Prochilodous scrofa fish exposed to increased copper concentration (Mazon et al., 2002). Similar trends were reported in the fish exposed to various pollutants in C. punctatus exposed to zinc (Tyagi and Srivastava, 2005).

\section{Conclusion}

Haematological characteristics are an important tool that can be used to understand as an effective and sensitive index to monitor physiological and pathological changes in fishes. Exposed of fish to tannery effluent showed a significant decrease in the haemoglobin $(\mathrm{Hb})$ content $(9.16 \pm 0.08)$, red blood cells $(3.32$ $\pm 0.12)$, packed cell volume $(34.66 \pm 0.33)$ and mean corpuscular haemoglobin $(\mathrm{MCH})$ values, whereas significant increase in the white blood cells (WBC), erythrocyte sedimentation rate (ESR) and clotting time was recorded with increase in exposure periods. Changes in haematological parameters depend on the aquatic biotope, fish species, age, and sexual maturity and health status. Haematological parameter are highly useful as the early warning for the process of xenobiotic and their effects, which make it possible to implement corrective measures before aquatic organisms and their communities suffer irreversible damage.

\section{REFERENCES}

Adakole, J.A. (2012). Changes in some haematological parameters of the African catfish (Clarias gariepinus) exposed to a metal finishing company effluent. Indian Journal of Science and Technology. 5: 4.

Adebisi, S.A., Ipinromiti, K.O. and Amoo, I.A. (2007). Heavy Metals Contents of Effluents and Receiving Waters from Various Industrial Groups and their Environs. J. Appl. Sci. 2(4): 345-348.

Adriano, D.C. (2001). Trace Elements in Terrestrial Environments: Biochemistry bioavailability and risks of metals. Springer Verlag. p.867. 
Anikwe, M. and Nwobodo, K.C.A. (2006). Long term effect of municipal waste disposal on soil properties and productivity of sites used for urban agriculture in Abakaliki, Nigeria. Bioresources Technol., 83: 241-251

APHA.(2005). Standard methods for the examination of water and wastewater, $21^{\text {st }}$ Edn., Wasington D.C.

Ates, B., Orun, I., Talas, Z.S., Durmaz, G. and Yilmaz, I . (2008). Effects of sodium selenite on some biochemical and hematological parameters of rainbow trout (Oncorhynchus mykiss Walbaum, 1792) exposed to $\mathrm{Pb} 2+$ and $\mathrm{Cu} 2+$. Fish Physiology and Biochemistry, 34: 53-59

Bakare, A.A., Lateef, A., Amuda, O.S. and Afolabi, R.O. (2003). The aquatic toxicity and characterization of chemical and microbiological constituents of water samples from Oba River, Odo-oba, Nigeria. Asian J. Microbiol Biotechnol. Environ. Sci., 5: 11-17

Bhagwant, S. and Bhikajee, M. (2000). Induction of hypochromic macrocytic anemia in Oreochromis hybrid (cichlidae) exposed to $100 \mathrm{mg} / \mathrm{l}$ (sublethal dose) of aluminium. Sci. Technol. Res. J., 5: 9-20

Bhatkar, N. V. (2010). Chromium, nickel and zinc induced alterations in the gills of the fresh water fish Labeo rohita. J. Appl. \& Nat. Sci., 2 (2): 234-238

Goodwin, T. H., Young, A. R., Holmes, M. G. R., Old, G. H., Hewitt, N., Leeks, G. J. L., Packman, J. C. and Smith, B. P. G. (2003). The temporal and spatial variability of sediment transport and yields within the Bradford Beck catchment, West Yorkshire. Sci. Total Environ., 314-316: 475-494

Haniffa, M. A. and Porchelvi, M. (1985). Effects of distillery effluents on oxygen consumption of freshwater fish, Sarotherodon mossambicus. J. Environ. Biol., 6: 17-23

Kori Siakpere, O., Ake, J. and Avworo, U. M. (2006). Sublethal effects of some selected haematological parameters of Heteroclarias (A hybrid of Heterobranchus bidorsalis and Clarias gariepinus). Int. J. Zool. Res., 2: 77-83

Kori-Siakpere, O. and Ubogu, E. O. (2008). Sublethal haematological effects of zinc on the freshwater fish, Heteroclarias sp. (Osteichthyes: Clariidae). African Journal of Biotechnology, 7 (12): 2068-2073

Larsson, A., Haux, C. and Sjobeck, M. (1985). Fish physiology and metal pollution. Result and experiences from laboratory and field studies. Ecotoxicol. Environ. Saf., 9: $250-281$

Mallesh, B., Pandey, P. K., Kumar, K., Vennila, A. and Kumar, S. (2015). Bioconcentration of hexavalent chromium in Cirrhinus mrigala (Ham 1822): effect on haematological parameters. Journal of Biology and Earth sciences, 5 (1): 59-67

Mazon, A.F., Cerqueira, C. and Fernandes, M.N. (2002). Gill cellular changes induced by copper exposure in the South American tropical fresh water fish Prochilodous scrofa. Environ. Res., 88: 52-63

Mishra, S., Sharma, D. and Melkania, V. (1988). Physicochemical .characterstics of effluents from a textile mill at Ra.lnpur and their effect on fish mortality. IXth annual Session of and national symposium on Fish. Assess and Management of Acad.

Morrison, M.L., Block, W.M., Strickland, M.D. and Kendall, W.L. (2001). Wildlife Study Design. New York: Springer-Verlag.

Nadal, M., Schuhmacher, M. and Domingo, D.L. (2004). Metal pollution of soils and vegetation in an area with petrochemical industries. Sci. Total Environ., 321(1-3): 59-69

Odiete, W.O. (1999). Impacts associated with water pollution in Environmental Physiology of Animals and Pollution. Diversified Resources Ltd, Lagos 1st edition. 187-219

Pawar, C. D. (1988). Studies on fish and fisheries of river, Panchganga. M.Phil. dissertation, Shivaji University, KoIhapur (India).

Sahu, R. K., Katiyar, S., Yadav, A. K., Kumar, N. and Srivastava, J. (2008). Toxicity Assessment of Industrial Effluent by Bioassays Clean. Soil, Air, Water, 36:517520

Shah, S.L. (2006). Haematological parameters in Tench, Tinca tinca after short term exposure to Lead. Journal of Applied Toxicology, 26 (3): 223-228

Shaheen, T. (2009). Studies on chromium toxicity in Cyprinus carpio brood stock progeny relationship. Ph.D Thesis, University of Punjab, Lahore, Pakistan.

Singh, M.(1995). Haematological responses in a fresh water teleost, Channa punctatus to experimental copper and Cr poisoning, J. Environ. Biol., 16:339-341

Singh, S. R. and Singh, B. R. (1982). Effect of Copper and Zinc Sulphate on the blood parameters of Mystus vittatus. Matsya, 8: 1-6

Singh, Y., Kant, K., Sharma, H.B. and Rana, K.S. (2008). Bioaccumulation of cadmium in Tissues of Cirrihna mrigala and Catla catla. Asia. J. Exp. Sci., 22(3): 411414

Sood, R. (1996). Haematology for Students and Practitioners Jaypee Brothers Medical Publishers (P) Ltd., New Delhi.

Sugasini, A. and Rajagopal, K.(2015). Characterization of Physicochemical Parameters and heavy metal Analysis of Tannery Effluent. Int. J. Curr. Microbiol. App., 4(9): 349-359

Tyagi, A. and Srivastava, N. (2005). Haematological response of fish Channa punctatus (Bloch) to chronic zinc exposure. $J$ Environ. Biol., 26(2 Suppl):429-432

Wintrobe, M.M. (1957). Clinical Haematology. Lea and Febiger, USA. 